\title{
A COMPARISON OF THE PERFORMANCE AND SOME PHYSIOLOGICAL STRESS OF LAYING HENS KEPT IN BATTERY CAGES AND ON FLOOR PENS SYSTEM
}

\author{
ALM EL DEIN, A. K. ${ }^{1}$, A. A. EL-SHAFEI ${ }^{2}$, \\ Y. A. ABD EL AZIZ ${ }^{1}$ and M. A. AL-GAMAL ${ }^{2}$
}
1. Animal Production Research Institute, ARC, Ministry of Agricultural, Dokki, Giza, Egypt.
2. Department of Animal Production, Faculty of Agriculture, Al-Azhar University, Nassr City, Cairo, Egypt.

(Manuscript received 5 June 2016)

\begin{abstract}
$\mathrm{O}$ ne hundred and eighty hens 18 weeks old were randomly chosen from a flock reared in deep litter system (from one day old) and used in this experiment. Hens were individual weighted and randomly divided into two equal groups ( 90 hens each). First group, hens were transferred from floor pens to conventional cages system at 18 weeks of age using 30 cages with 3 birds per cage, each cage considered as a replicate. Second group was still in floor pens with 6 hens per square meter, divided to 3 replicates, each replicate 30 hens, to evaluate the effects of transference hens from floor pens ( $F$. .) to conventional cages system (Con.) at 18 weeks of age, compared to others which still in floor pens during the first season of egg production (from 20-52 weeks of age) on productive performance and some physiological stress parameters of laying hens. The main results were as follows: After hens were transferred from floor pens to conventional cages at 18 weeks of age, hens which were still in floor pens had significantly heavier body weight at 20 and 24 weeks of age. Also, feed conversion ratio, egg production percentage and egg weight at 24 weeks of age were significantly $(P<0.05)$ better. Although, feed consumption was insignificantly higher in conventional cages compared to floor pens system. In general, there was no significant effect between two systems on all parameters that were measured in table (1) from week 28 until week 52. There were significantly ( $P$ $<0.05)$ increased in plasma Heterophil/Lymphocyte $(\mathrm{H} / \mathrm{L})$ ratio, serum corticosterone and glucose at 20,24 and 28 weeks of age for hens which transferred to conventional cages at 18 weeks of age compared to others still on floor pens system. Furthermore, the results of egg albumen and yolk corticosterone concentrations were in same trend of previous results where the concentrations of corticosterone in egg albumen and yolk were significantly $(P<$ 0.05 ) higher in the hens housed in conventional cages at week 24, 28 and 32 of the age compared to the hens housed on floor pens. Moreover, there were no significant effects of the two housing systems at all parameters that were measured in table (2) from the week 36 until the end of the experiment. From the previous results it could be concluded that hens which transferred from floor pens to conventional cages system at 18 weeks of age were stressed at the start of lay, but adapt to their new environment when hens grew older towards the end of the laying period. Finally, it could be recommended to transfer hens from floor pens to conventional
\end{abstract}


cages system to spend eggs laying period in this system (conventional cages system) which consider much better hygienic standards environment than floor pens system.

Key words: laying hens, housing system, productive performance, physiological stress parameters.

\section{INTRODUCTION}

Different housing systems for laying hens have considerable effects on performance and production traits (Süto et al., 1997).

Free-run system create higher dust levels, increased emissions of ammonia, collection of floor eggs and thereby more available to the bacterial contamination, as well as the risk of outbreaks which leading to decreased hatchability or marketability, greater labor costs for egg collection and cannibalism in large flocks of birds, which consider negative sides in litter floor system (Appleby, 1984).

Duncan (2001) analyzed advantages and disadvantages of conventional cage system. He considered the absence of problems resulting from litter as the main advantages, also, low incidence of diseases for example, Singh et al. (2009a) reported that eggs from cages had lower E. coli and coliform contamination than those from nests and the floor. Thereby, this is in harmony with fact that conventional cage system is much better hygienic standards and the most economical pattern for the commercial layer industry. The disadvantages were found to be a lack of both physical and psychological space of laying hens for daily activities (nesting, perching, poking, flaunt, dust bathing opportunities and other ethological needs), and a higher incidence of foot lesions. Therefore, it is widely considered to have a negative effect on the welfare of hens (Craig and Swanson, 1994). For this reason, it has been criticized by animal welfare organizations (e.g., Farm Animal Welfare Council,1986) and there has been pressure to ban conventional cages in Europe in 2012,

Even though North America considered conventional cages the standard industry practice and there are no regulations in place to prohibit the use of these types of cages. For example, United States and Canada are still legal, of the approximately 300 million egg-laying chickens (95\%) and 26 million egg laying hens (98\%) produced in the United States and Canada respectively, confined in conventional wire cages (USDA, 2005 and Canadian Coalition for Farm Animals, 2005).

The objective of this study was to evaluate the effects of transference hens from floor pens system to conventional cages system at 18 weeks of age, compared to others which still in floor pens during the first season of egg production (from 20-52 weeks 
of age) on productive performance and some physiological stress parameters of laying hens.

\section{MATERIALS AND METHODS}

This work was carried out at Poultry Experimental Station, Animal Production Department, Faculty of Agriculture, Al-Azhar University, Cairo, Egypt.

\section{Birds and experimental design:}

A total number of 180 hens of Lohmann Selected Leghorn (LSL) which is a Single Comb White Leghorn commercial strain at 18 weeks of age were randomly chosen from a flock reared in deep litter system (from one day up to 18 weeks old) were used in this experiment. Hens were individual weighted and randomly divided into two equal groups (90 hens each). First group, hens were transferred from floor pens to 30 cages with 3 hens per cage of conventional cages system at 18 weeks of age. The area of each cage was $40 \times 45 \times 45 \mathrm{~cm}^{3}$ (width $\times$ depth $\times$ height respectively), $600 \mathrm{~cm}^{2} /$ bird, each cage considered as a replicate. Cages were arranged on 3 tiers in double-sided rows. Each cage was provided with a feeder in front and 1 nipple drinker at the back. Second group was remained in floor pens with 6 hens per square meter, divided to 3 replicates, each replicate 30 hens and provided with 1 nest for each 5 birds. Feed and water were provided ad libitum and the diets were presented in mash from contained a $18 \%$ crude protein and $2800 \mathrm{Kcal}$ metabolizable energy $/ \mathrm{Kg}$ until the end of the experiment period (Table 1). Light was provided 17 hours daily during the experimental period. All hens were vaccinated following a program typical of the region, and hens reared on the floor were also vaccinated against coccidiosis. In both housing systems, hens started lying at approximately 20 week, and the laying trial was continued until the hens were reached 52 week of age. Every day egg production per cage or pen was recorded, weighed and egg production was calculated as a henday basis. Feed consumption was measured monthly from 20 to 52 week of age. Feed conversion was calculated by (gram feed/gram egg) during the time that feed consumption was measured.

\section{Blood Heterophil/Lymphocyte (H/L) Ratio:}

Blood was sampled for $\mathrm{H} / \mathrm{L}$ ratio monthly when birds in period between (20 to 52) weeks of age. A total of 28 hens were randomly selected from each housing system for taking blood samples. Two drops of blood were taken from the right brachial vein within a minute of catching the hen (Broom and Knowles, 1989) and were dropped separately into the slide. All blood samples were collected at the morning of the first day of each month in the same time. Blood samples were stained 
with May- Gru"nwald-Giemsa stain (Gross and Siegel, 1983). On each slide, heterophils and lymphocytes were counted until a total of 100 cells were reached using a light microscope at $\times 1000$ magnification. $H / L$ ratios were determined by dividing the number of heterophils into the number of lymphocytes.

\section{Blood corticosterone and glucose:}

Blood samples were taken in tubes without anticoagulants (serum) to determine corticosterone hormone levels. Few drops of blood were taken from the right brachial vein within a minute of catching the hen (Broom and Knowles, 1989). All blood samples were centrifuged and plasma samples were decanted into Eppendorf tubes and stored at $\left(-20^{\circ} \mathrm{C}\right)$ until analyzed for both corticosterone and glucose. Serum corticosterone levels were measured using the kits (Gamma-B ${ }^{125} \mathrm{I}$ Corticosterone, Code AA-13 F1) for IDS double antibody RIA technique, with a Berthold LB211 gamma counter. Serum glucose was determined using a Hitachi Autoanalyzer (Hitachi, Tokyo; Serial Number 1238-23) and it's accompanying commercial kits.

\section{Egg Corticosterone Assay:}

One egg was collected from 28 hens, of each housing system in the first day of each month, for measuring corticosterone in yolk and albumen from 24 to 52 weeks of age. The albumen was separated from the yolk and both were freeze-dried, homogenized, and stored at $-20^{\circ} \mathrm{C}$ for further analysis. Extraction procedures for yolk and albumen were carried out according to Cook et al. (2009), and corticosterone was assayed using Assay Design Corticosterone Enzyme Immunoassay kits (901-097, Assay Designs Inc., Ann Arbor, MI) as per the instructions provided with the kit.

Briefly, approximately $100 \mathrm{mg}$ of yolk was weighed and vortexes for 30 second with 2 glass beads in $500 \mu \mathrm{L}$ of water, after which $5 \mathrm{~mL}$ of petroleum ether:diethyl ether (30:70 vol $/ \mathrm{vol})$ was added, and the mixture was vortexed for 1 min. After centrifugation at $2,800 \times g$ for $5 \mathrm{~min}$, the mixture was frozen at $-80^{\circ} \mathrm{C}$, and the supernatant was transferred to a $10-\mathrm{mL}$ glass tube and dried at $40^{\circ} \mathrm{C}$. The sample was reconstituted in $1 \mathrm{~mL}$ of $90 \%$ ethanol, vortexed until dissolved, and frozen at $-80^{\circ} \mathrm{C}$. The ethanol sample was allowed to thaw and centrifuged at $2,500 \times g$ at $4^{\circ} \mathrm{C}$ for $5 \mathrm{~min}$. The supernatant was decanted into a new 10-mL tube. Two milliliters of hexane was added, and the mixture was vortexed for 30 second, centrifuged at 2,500 $\times g$ at $4^{\circ} \mathrm{C}$ for $1 \mathrm{~min}$, and frozen at $-80^{\circ} \mathrm{C}$. The hexane layer was removed and discarded and the ethanol extract was dried at $40^{\circ} \mathrm{C}$. The dried extract was reconstituted immediately in $500 \mu \mathrm{L}$ of assay buffer, and the samples were transferred to a micro tubes and centrifuged at $14,000 \times g$ at $4^{\circ} \mathrm{C}$ for $15 \mathrm{~min}$. 
Approximately $50 \mathrm{mg}$ of albumen was vortexed for 10 second with 2 glass beads in $1 \mathrm{~mL}$ of water. Five milliliters of petroleum ether and diethyl ether (30:70 $\mathrm{vol} / \mathrm{vol}$ ) mix-ture was added and vortexed for $10 \mathrm{sec}$. After centrifugation at 3,500 $\times \mathrm{g}$ for $5 \mathrm{~min}$, the mixture was frozen at $-80^{\circ} \mathrm{C}$ and the supernatant transferred to a 10 $\mathrm{mL}$ glass tube and dried at $40^{\circ} \mathrm{C}$. The sample was reconstituted in $500 \mu \mathrm{L}$ of water, vortexed for 10 second, $2 \mathrm{~mL}$ of petroleum ether was added, and the mixture was vortexed for 10 second, centrifuged at $3,500 \times \mathrm{g}$, and frozen at $-80^{\circ} \mathrm{C}$. The supernatant was decanted into a new $10-\mathrm{mL}$ tube and dried at $40^{\circ} \mathrm{C}$. The dried extract was reconstituted in $500 \mu \mathrm{L}$ of assay buffer and centrifuged at $14,000 \times g$ at $4^{\circ} \mathrm{C}$ for $15 \mathrm{~min}$.

\section{Statistical analysis:}

The obtained data were subjected to one-way analysis of variance using analysis of procedure of (SAS, 2000). Significant differences among treatment means were determined by using Duncan's Multiple Range Test (Duncan, 1955); using the following model:

Yij $=\mu+\mathrm{Ni}+$ eij

Where $Y i j=$ observation for each dependent variable, $\mu=$ population means, $\mathrm{Ni}=$ effect of treatment, eij = the standard error.

\section{RESULTS}

\section{Productive performance:}

Body weight, feed consumption, feed conversion, egg production percentage and egg weight of LSL hens housed in floor pens or conventional cages system during the period from 20-52 weeks of age are presented in Table (2). After hens were transferred from floor pens to conventional cages at 18 weeks of age, hens which were still in floor pens had significantly heavier body weight at 20 and 24 weeks of age. Also, feed conversion ratio, egg production percentage and egg weight at 24 weeks of age were significantly $(P<0.05)$ better for the group reared on floor pens compared to others which were transferred to conventional cages. Although, feed consumption was insignificantly higher in conventional cages compared to floor pens system. In general, there was no significant effect between the two systems on all parameters that were measured in this study from week 28 until week 52 such as body weight, feed consumption, feed conversion, egg production percentage and egg weight. However, there was insignificant increase in both body weight and egg production percentage as the age increased for group of hens transferred to 
conventional cage system particularly from week 32 to week 52 of the age compared to hens reared on floor pens.

\section{Physiological parameters:}

Effect of both housing systems of LSL hens on results of serum heterophils to lymphocytes ratio, blood corticosterone and glucose, yolk and albumen corticosterone concentrations are presented in Table (3). The results showed that there were significantly $(P<0.05)$ increased in plasma $H / L$ ratio, serum corticosterone and glucose at 20, 24 and 28 weeks of age for hens which transferred to conventional cages (at 18 weeks of age) compared to others still on floor pens system. Furthermore, the results of egg albumen and yolk corticosterone concentrations were in the same trend of previous results where the concentrations of corticosterone in egg albumen and yolk were significantly $(P<0.05)$ higher in the hens housed in conventional cages at week 24, 28 and 32 of the age compared to the hens housed on floor pens. Moreover, there were no significant effects of the two housing systems on all previous parameters studied in table (2) from the week 36 until the end of the experiment. While, there were numerical increase in the concentration of yolk corticosterone for hens housed in conventional cages from week 36 till week 52 of the age compared to hens housed on floor pens.

\section{DISCUSSION}

Body weight at 20 and 24 weeks of age also feed conversion, egg production percentage and egg weight at 24 weeks of age were significantly $(P<0.05)$ higher in the hens housed on floor pens compared to conventional cage system, then, these effects were disappeared in period from 32 to 52 weeks of age, although, feed consumption was insignificantly higher in conventional cages compared to floor pens system at all periods studied because food is partitioned between body function, including maintenance, growth, reproduction and health. In healthy animals, $10 \%$ of food ingredients consumed are used to maintain health, while the remaining portion is divided into three equal parts for reproduction, maintenance and growth (Siegel and Gross, 2000). In stress, most of the consumed food is used to cope with unpleasant conditions (Siegel and Gross, 2000). It means that hens that transport from floor pens to conventional cages system at 18 weeks of age were under stress which, agree with the results reported by (Anderson et al., 1989), they suggested that pullets reared on floor are subjected to a drastic change in environment when housed in cages, the hypothesis considered that until adaptation of new environment (conventional cages) 
can cause some economic losses under commercial conditions and impair animal production.

Plasma $H / L$ ratio increased significantly for hens which transferred to conventional cages (at 18 weeks of age) compared to others still on floor pens system at 20,24 and 28 weeks of age. It means that hens in conventional cages system were under stress for the following reasons: First, the space which allow for bird is smaller for a hen in conventional cages imposes severe restrictions on hens' general freedom of movement compared to floor pens and thereby, more movement in floor pens compared to conventional cages system resulted in a less stressful environment in floor pens compared to conventional cages system; Second, the confinement in conventional cages physically restrict hens and eliminate many of their natural behaviors such as nesting, roosting, scratching and restricted locomotor activity such as wing-flapping. While, free-run systems allow expression of a greater behavioral repertoire compared to conventional cages system; Third, greater visual access to their surroundings afforded by floor pens compared to conventional cages system and Fourth, like all domestic animals, laying hens are highly social, which is existing in floor pens system than in conventional cages system. (Tactacan et al., 2009). These results are in accordance with Mc Farlance and Curtis (1989) who suggested that the increased in $\mathrm{H} / \mathrm{L}$ ratio was associated with increased environment stress.

Also, significantly higher of serum corticosterone concentration in the conventional cages at 20, 24 and 28 weeks of age compared to floor pens system which found in the present study could reflect higher stress conditions because, during stress conditions, neural impulse activate hypothalamus and are converted to neurohumoral factors (corticotropin-releasing factors) stimulates the anterior hypophysis to secrete Adrenocorticotrophic hormone (ACTH) which in turn, stimulated the adrenal gland for corticosterone secretion (Hill,1983). Increasing serum corticosterone described as an important indicator for stress conditions and leading to 1) increasing serum glucose level due to the effect of glucocorticoids (Simon, 1984) and 2) an increase in heterophil count and decline in lymphocyte count (Hill, 1983). In the avian, heterophil $(\mathrm{H})$ and lymphocyte $(\mathrm{L})$ are more responsive to stressors than the other leukocytes, making their differential response less difficult to detect than differences among the others, therefore, the $\mathrm{H}: \mathrm{L}$ ratio has found to be successful indicator of stress (Maxwell et al., 1992).

Handling is a known stressor that has been reported to increase blood corticosterone concentrations in response to as little as 45 second of handling, with concentrations remaining elevated from anywhere between 30 minutes and 3 hours, depending of the severity of the handling (Broom and Knowles, 1989). Consequently, 
it is virtually impossible to obtain frequent serial blood samples from individual birds without the confounding effects of handling. For this reason the scientists were searching for alternative, non-invasive sampling media such as excreta material (eggs) for corticosteroid measurements, which have biological validity for assessing the stress responses of birds. Corticosterone assays in eggs are becoming popular, noninvasive techniques for measuring stress in hens (Downing and Bryden, 2002).

In this study, significantly higher yolk and albumen corticosterone concentrations in eggs from conventional cages system at 24, 28 and 32 weeks of age are similar to our finding for both serum corticosterone, $\mathrm{H}: \mathrm{L}$ ratio and glucose which suggested that hens in cages were under stress for both the (6) hours period of albumen deposition and the (10) days period of yolk formation and demonstrate that yolk corticosterone was higher than in albumen. Therefore, the levels of corticosterone in the albumen may better reflect short-term stress (Downing and Bryden, 2002) than those in the yolk which consider long-term stress (Johnson, 1986) and could provide an integrated reflection of circulating blood corticosterone over these periods, thereby providing noninvasive measures of short-term and long-term stress, in laying hens respectively. Our results were in harmony with Cook, et al. (2009) demonstrated that egg measurements of corticosterone may have a more useful role in monitoring changes in adrenocortical output over time, and possibly have utility as biomarkers of chronic stress in laying hens. Also, these results are agree with Downing and Bryden, (2009) as pointed out, that subtle changes in plasma corticosterone concentrations could be amplified in egg albumen because of the period over which the albumen accumulate and could provide a better indication of corticosterone concentrations than single point blood samples.

After 28 wks of age all measurements in table (3) had comparable values between conventional cages and floor pens system until the 52 weeks of age, except yolk corticosterone which had the same trend but after 32 wks of age, which means that these parameters in conventional cages decreased when hens grew older. These findings coincided with Singh et al. (2009b) they noticed that hens housed in cages, both the yolk corticosterone concentrations and the blood $\mathrm{H} / \mathrm{L}$ ratio decreased with age, which may be a demonstration of the adaptation of the hens to their environment towards the end of the laying period.

It could be concluded that, although hen-day egg production percentage and egg weight were significantly lower for hens which transferred from floor pens to conventional cages system at 18 weeks of age compared to others which still in floor pens system until 24 weeks of age due to the stress of conventional cages system as proved with physiological stress parameters (plasma heterophils to lymphocytes ratio, 
Corticosterone, glucose and both yolk and albumen corticosterone concentrations) which were significantly higher in conventional cages compared to floor pens system, but the reverse effect was true with insignificant values (slight increase) in body weight, hen-day egg production percentage and egg weight from 32 to 52 weeks of age. This means that the hens transferred from floor pens to conventional cages system at 18 weeks of age were stressed at the start of lay, but adapt to their new environment when hens grew older towards the end of the laying period. Finally, it could be recommended to transfer hens from floor pens to conventional cages system to spend eggs laying period in this system (conventional cages system) which consider much better hygienic standards environment than floor pens system.

Table 1. Composition and calculated analysis of experimental diet of L.S.L. chicken.

\begin{tabular}{|l|c|}
\hline \multicolumn{1}{|c|}{ Ingredients } & Quantity (Kg) \\
\hline Ground yellow corn 8.8\% & 59 \\
\hline Soybean meal 44\% & 9 \\
\hline Corn gluten meal 60\% & 14.09 \\
\hline Wheat bran 15.7\% & 6.45 \\
\hline Dicalcium phosphate & 1.9 \\
\hline Limestone & 8.6 \\
\hline 1Vitamin and mineral premix & 0.3 \\
\hline Sodium Chloride (NaCl) & 0.3 \\
\hline DL-methionine & 0.1 \\
\hline L-lysine-HCl & 0.26 \\
\hline Total (Kg) & 100 \\
\hline Calculated analysis & \\
\hline Crude protein\% & 18 \\
\hline ME. Cal/Kg feed & 2797 \\
\hline C/P ratio & 155.39 \\
\hline Calcium\% & 3.73 \\
\hline Available Ph.\% & 0.46 \\
\hline Lysine\% & 0.84 \\
\hline Methionine\% & 0.46 \\
\hline Methionine + Cystin\% & \\
\hline Composition of vitamin and $\%$ & \\
\hline
\end{tabular}

${ }^{1}$ Composition of vitamin and mineral premix. Each $3 \mathrm{Kg}$ of vitamin and minerals mixture contain: Vit. A 10,000,000 IU, Vit. D3 2,000,000 IU, Vit. E 10,000 mg, Vit. K3 1,000 mg Vit. B1 1,000 mg, Vit. B2 5,000 mg, Vit. B6 1,500 mg, Vit B12 10 mg, Niacin 20,000 mg, Pantothenic acid 10,000 mg, Folic acid 1,000 mg, Biotin $50 \mathrm{mg}$, Choline chloride 500,000 mg, Copper 4,000 mg, Iodine $300 \mathrm{mg}$, Iron 30,000 mg, Manganese $60,000 \mathrm{mg}$, Zinc 50,000 mg, Cobalt $100 \mathrm{mg}$ and Selenium $100 \mathrm{mg}$. 
Table 2. Means \pm SE of some productive traits of White Lohmann (LSL) laying hens as affected by Floor pens (F.) or Conventional cage (con.) systems.

\begin{tabular}{|c|c|c|c|c|c|c|c|c|c|c|}
\hline \multirow[t]{2}{*}{ Age } & \multicolumn{2}{|c|}{ Body Weight (g) } & \multicolumn{2}{|c|}{$\begin{array}{c}\text { Feed Consumption } \\
\text { (g diet/hen/day) }\end{array}$} & \multicolumn{2}{|c|}{$\begin{array}{c}\text { Feed Conversion } \\
\text { (g diet/g eggs) }\end{array}$} & \multicolumn{2}{|c|}{$\begin{array}{c}\text { Egg Production } \\
(\%)\end{array}$} & \multicolumn{2}{|c|}{ Egg Weight (g) } \\
\hline & $\mathrm{F}$. & Con. & $\mathrm{F}$. & Con. & F. & Con. & F. & Con. & F. & Con. \\
\hline $\begin{array}{c}20 \\
(\mathrm{Wks})\end{array}$ & $\begin{array}{l}1337^{\mathrm{a}} \\
\pm 8.13\end{array}$ & $\begin{array}{l}1263^{b} \\
\pm 8.45\end{array}$ & $\begin{array}{l}114.56 \\
\pm 6.15\end{array}$ & $\begin{array}{c}116.08 \\
\pm 7.43\end{array}$ & - & - & - & - & - & - \\
\hline $\begin{array}{c}24 \\
\text { (Wks) }\end{array}$ & $\begin{array}{l}1531^{\mathrm{a}} \\
\pm 7.54\end{array}$ & $\begin{array}{l}1487^{b} \\
\pm 8.71\end{array}$ & $\begin{array}{c}114.98 \\
\pm 7.42\end{array}$ & $\begin{array}{c}116.84 \\
\pm 6.49\end{array}$ & $\begin{array}{l}2.20^{\mathrm{b}} \\
\pm 0.12\end{array}$ & $\begin{array}{l}2.31^{\mathrm{a}} \\
\pm 0.09\end{array}$ & $\begin{array}{l}59.2^{\mathrm{a}} \\
\pm 1.79\end{array}$ & $\begin{array}{c}51.7^{\mathrm{b}} \\
\pm 1.58\end{array}$ & $\begin{array}{l}52.1^{\mathrm{a}} \\
\pm 0.74\end{array}$ & $\begin{array}{c}50.4^{\mathrm{b}} \\
\pm 0.59\end{array}$ \\
\hline $\begin{array}{c}28 \\
(\mathrm{Wks})\end{array}$ & $\begin{array}{c}1622 \\
\pm 8.16\end{array}$ & $\begin{array}{c}1595 \\
\pm 7.58\end{array}$ & $\begin{array}{c}116.94 \\
\pm 6.71\end{array}$ & $\begin{array}{c}117.69 \\
\pm 7.20\end{array}$ & $\begin{array}{c}2.04 \\
\pm 0.11\end{array}$ & $\begin{array}{c}2.06 \\
\pm 0.12\end{array}$ & $\begin{array}{c}78.4 \\
\pm 1.46 \\
\end{array}$ & $\begin{array}{c}76.9 \\
\pm 1.71 \\
\end{array}$ & $\begin{array}{c}57.3 \\
\pm 0.63\end{array}$ & $\begin{array}{c}56.9 \\
\pm 0.54 \\
\end{array}$ \\
\hline $\begin{array}{c}32 \\
(W k s)\end{array}$ & $\begin{array}{c}1653 \\
\pm 7.81 \\
\end{array}$ & $\begin{array}{c}1669 \\
\pm 8.52 \\
\end{array}$ & $\begin{array}{l}118.23 \\
\pm 6.47\end{array}$ & $\begin{array}{c}118.32 \\
\pm 6.59 \\
\end{array}$ & $\begin{array}{c}1.96 \\
\pm 0.09 \\
\end{array}$ & $\begin{array}{c}1.96 \\
\pm 0.10 \\
\end{array}$ & $\begin{array}{c}91.6 \\
\pm 1.53 \\
\end{array}$ & $\begin{array}{c}92.3 \\
\pm 1.24 \\
\end{array}$ & $\begin{array}{c}60.2 \\
\pm 0.61 \\
\end{array}$ & $\begin{array}{c}60.3 \\
\pm 0.70\end{array}$ \\
\hline $\begin{array}{c}36 \\
\text { (Wks) }\end{array}$ & $\begin{array}{c}1687 \\
\pm 8.63\end{array}$ & $\begin{array}{c}1698 \\
\pm 7.85\end{array}$ & $\begin{array}{l}118.84 \\
\pm 6.47\end{array}$ & $\begin{array}{c}119.02 \\
\pm 7.11\end{array}$ & $\begin{array}{c}1.93 \\
\pm 0.12\end{array}$ & $\begin{array}{c}1.92 \\
\pm 0.11\end{array}$ & $\begin{array}{c}90.4 \\
\pm 1.26\end{array}$ & $\begin{array}{c}92.1 \\
\pm 1.74\end{array}$ & $\begin{array}{c}61.3 \\
\pm 0.74\end{array}$ & $\begin{array}{c}61.7 \\
\pm 0.68\end{array}$ \\
\hline $\begin{array}{c}40 \\
(W k s)\end{array}$ & $\begin{array}{c}1708 \\
\pm 7.81 \\
\end{array}$ & $\begin{array}{r}1715 \\
\pm 7.06 \\
\end{array}$ & $\begin{array}{c}118.92 \\
\pm 7.23 \\
\end{array}$ & $\begin{array}{l}119.31 \\
\pm 6.52 \\
\end{array}$ & $\begin{array}{c}1.91 \\
\pm 0.09 \\
\end{array}$ & $\begin{array}{c}1.90 \\
\pm 0.11 \\
\end{array}$ & $\begin{array}{c}89.1 \\
\pm 1.82 \\
\end{array}$ & $\begin{array}{c}91.3 \\
\pm 1.26 \\
\end{array}$ & $\begin{array}{c}62.1 \\
\pm 0.67 \\
\end{array}$ & $\begin{array}{r}62.5 \\
\pm 0.61 \\
\end{array}$ \\
\hline $\begin{array}{c}44 \\
(\mathrm{Wks})\end{array}$ & $\begin{array}{c}1714 \\
\pm 8.61 \\
\end{array}$ & $\begin{array}{c}1727 \\
\pm 8.12 \\
\end{array}$ & $\begin{array}{l}119.25 \\
\pm 6.75 \\
\end{array}$ & $\begin{array}{c}119.64 \\
\pm 6.71 \\
\end{array}$ & $\begin{array}{c}1.90 \\
\pm 0.10 \\
\end{array}$ & $\begin{array}{c}1.90 \\
\pm 0.12 \\
\end{array}$ & $\begin{array}{c}86.3 \\
\pm 1.22 \\
\end{array}$ & $\begin{array}{c}87.1 \\
\pm 1.36 \\
\end{array}$ & $\begin{array}{c}62.7 \\
\pm 0.55 \\
\end{array}$ & $\begin{array}{c}62.9 \\
\pm 0.63 \\
\end{array}$ \\
\hline $\begin{array}{c}48 \\
\text { (Wks) }\end{array}$ & $\begin{array}{c}1719 \\
\pm 7.26 \\
\end{array}$ & $\begin{array}{c}1731 \\
\pm 7.69 \\
\end{array}$ & $\begin{array}{c}119.48 \\
\pm 7.45 \\
\end{array}$ & $\begin{array}{c}120.06 \\
\pm 6.77 \\
\end{array}$ & $\begin{array}{c}1.90 \\
\pm 0.12 \\
\end{array}$ & $\begin{array}{c}1.90 \\
\pm 0.10 \\
\end{array}$ & $\begin{array}{c}82.0 \\
\pm 1.41 \\
\end{array}$ & $\begin{array}{c}83.2 \\
\pm 1.78 \\
\end{array}$ & $\begin{array}{c}62.8 \\
\pm 0.59 \\
\end{array}$ & $\begin{array}{c}63.1 \\
\pm 0.50 \\
\end{array}$ \\
\hline $\begin{array}{c}52 \\
\text { (Wks) }\end{array}$ & $\begin{array}{c}1722 \\
\pm 7.53\end{array}$ & $\begin{array}{c}1734 \\
\pm 8.18\end{array}$ & $\begin{array}{l}119.77 \\
\pm 7.42\end{array}$ & $\begin{array}{c}120.94 \\
\pm 6.79\end{array}$ & $\begin{array}{c}1.90 \\
\pm 0.09\end{array}$ & $\begin{array}{c}1.91 \\
\pm 0.11\end{array}$ & $\begin{array}{c}76.4 \\
\pm 1.82\end{array}$ & $\begin{array}{c}77.6 \\
\pm 1.46\end{array}$ & $\begin{array}{c}62.9 \\
\pm 0.56\end{array}$ & $\begin{array}{c}63.0 \\
\pm 0.61\end{array}$ \\
\hline
\end{tabular}

F. = Floor pens system, Con. = Conventional cage system

$A, b, \ldots . .$. Means within each parameter in the same row with different superscript letters are significantly different $(p \leq 0.05)$.

Table 3. Means \pm SE of some physiological parameters of White Lohmann (LSL) laying hens as affected by Floor pens ( $F$.) or Conventional cage (con.) systems.

\begin{tabular}{|c|c|c|c|c|c|c|c|c|c|c|}
\hline \multirow[t]{2}{*}{ Age } & \multicolumn{2}{|c|}{$\begin{array}{c}\text { Plasma } \\
\text { H/L Ratio }\end{array}$} & \multicolumn{2}{|c|}{$\begin{array}{c}\text { Serum } \\
\text { Corticoserone } \\
(\mathrm{ng} / \mathrm{ml})\end{array}$} & \multicolumn{2}{|c|}{$\begin{array}{c}\text { Serum } \\
\text { Glucose } \\
(\mathrm{mg} / \mathrm{dl})\end{array}$} & \multicolumn{2}{|c|}{$\begin{array}{c}\text { Albumin } \\
\text { Corticoserone } \\
((\mathrm{pg} / \mathrm{mg})\end{array}$} & \multicolumn{2}{|c|}{$\begin{array}{c}\text { Yolk } \\
\text { Corticoserone } \\
((\mathrm{pg} / \mathrm{mg})\end{array}$} \\
\hline & $\mathrm{F}$. & Con. & $\mathrm{F}$. & Con. & $\mathrm{F}$. & Con. & $\mathrm{F}$. & Con. & $\mathrm{F}$. & Con. \\
\hline $\begin{array}{c}20 \\
(\mathrm{Wks})\end{array}$ & $\begin{array}{c}0.23 \mathrm{~b} \\
\pm 0.004\end{array}$ & $\begin{array}{c}0.28 \mathrm{a} \\
\pm 0.003\end{array}$ & $\begin{array}{l}1.78 \mathrm{~b} \\
\pm 0.07\end{array}$ & $\begin{array}{l}1.87 \mathrm{a} \\
\pm 0.06\end{array}$ & $\begin{array}{c}224.13 \mathrm{~b} \\
\pm 8.56\end{array}$ & $\begin{array}{c}239.46 \mathrm{a} \\
\pm 9.18\end{array}$ & - & - & - & - \\
\hline $\begin{array}{c}24 \\
(\mathrm{Wks})\end{array}$ & $\begin{array}{c}0.23 \mathrm{~b} \\
\pm 0.004 \\
\end{array}$ & $\begin{array}{r}0.27 \mathrm{a} \\
\pm 0.005 \\
\end{array}$ & $\begin{array}{l}1.77 \mathrm{~b} \\
\pm 0.08\end{array}$ & $\begin{array}{l}1.84 \mathrm{a} \\
\pm 0.07\end{array}$ & $\begin{array}{c}226.42 \mathrm{~b} \\
\pm 7.86\end{array}$ & $\begin{array}{c}245.74 \mathrm{a} \\
\pm 8.91\end{array}$ & $\begin{array}{c}23.82 \mathrm{~b} \\
\pm 1.82\end{array}$ & $\begin{array}{c}26.14 \mathrm{a} \\
\pm 1.90\end{array}$ & $\begin{array}{c}26.52 \mathrm{~b} \\
\pm 1.34 \\
\end{array}$ & $\begin{array}{c}33.64 \mathrm{a} \\
\pm 1.49 \\
\end{array}$ \\
\hline $\begin{array}{c}28 \\
(\mathrm{Wks}) \\
\end{array}$ & $\begin{array}{c}0.24 b \\
\pm 0.003\end{array}$ & $\begin{array}{c}0.27 \mathrm{a} \\
\pm 0.004\end{array}$ & $\begin{array}{l}1.75 \mathrm{~b} \\
\pm 0.05 \\
\end{array}$ & $\begin{array}{l}1.82 \mathrm{a} \\
\pm 0.07 \\
\end{array}$ & $\begin{array}{c}223.78 \mathrm{~b} \\
\pm 8.54\end{array}$ & $\begin{array}{c}253.44 \mathrm{a} \\
\pm 9.33\end{array}$ & $\begin{array}{c}22.35 b \\
\pm 1.74\end{array}$ & $\begin{array}{c}25.73 \mathrm{a} \\
\pm 1.87\end{array}$ & $\begin{array}{c}25.71 b \\
\pm 1.33\end{array}$ & $\begin{array}{l}32.92 \mathrm{a} \\
\pm 1.161 \\
\end{array}$ \\
\hline $\begin{array}{c}32 \\
\text { (Wks) }\end{array}$ & $\begin{array}{c}0.24 \\
\pm 0.004\end{array}$ & $\begin{array}{c}0.25 \\
\pm 0.003\end{array}$ & $\begin{array}{c}1.76 \\
\pm 0.08\end{array}$ & $\begin{array}{c}1.78 \\
\pm 0.08\end{array}$ & $\begin{array}{l}225.96 \\
\pm 7.45\end{array}$ & $\begin{array}{c}231.04 \\
\pm 8.67\end{array}$ & $\begin{array}{l}22.86 \\
\pm 1.65\end{array}$ & $\begin{array}{l}23.84 \\
\pm 1.78\end{array}$ & $\begin{array}{c}24.69 \mathrm{~b} \\
\pm 1.41\end{array}$ & $\begin{array}{c}32.04 \mathrm{a} \\
\pm 1.56\end{array}$ \\
\hline $\begin{array}{c}36 \\
(\mathrm{Wks})\end{array}$ & $\begin{array}{c}0.24 \\
\pm 0.005\end{array}$ & $\begin{array}{c}0.23 \\
\pm 0.004\end{array}$ & $\begin{array}{c}1.76 \\
\pm 0.07\end{array}$ & $\begin{array}{c}1.75 \\
\pm 0.05\end{array}$ & $\begin{array}{l}227.03 \\
\pm 7.82\end{array}$ & $\begin{array}{c}228.17 \\
\pm 8.09\end{array}$ & $\begin{array}{l}22.54 \\
\pm 1.76\end{array}$ & $\begin{array}{l}23.01 \\
\pm 1.83\end{array}$ & $\begin{array}{l}25.92 \\
\pm 1.38\end{array}$ & $\begin{array}{l}28.71 \\
\pm 1.32\end{array}$ \\
\hline $\begin{array}{c}40 \\
(\mathrm{Wks})\end{array}$ & $\begin{array}{c}0.23 \\
\pm 0.003\end{array}$ & $\begin{array}{c}0.24 \\
\pm 0.003\end{array}$ & $\begin{array}{c}1.77 \\
\pm 0.06\end{array}$ & $\begin{array}{c}1.76 \\
\pm 0.05\end{array}$ & $\begin{array}{l}224.95 \\
\pm 6.84\end{array}$ & $\begin{array}{c}225.16 \\
\pm 7.32\end{array}$ & $\begin{array}{l}22.42 \\
\pm 1.68\end{array}$ & $\begin{array}{l}22.21 \\
\pm 1.74\end{array}$ & $\begin{array}{l}24.46 \\
\pm 1.52\end{array}$ & $\begin{array}{l}26.54 \\
\pm 1.44\end{array}$ \\
\hline $\begin{array}{c}44 \\
(\mathrm{Wks})\end{array}$ & $\begin{array}{c}0.23 \\
\pm 0.004\end{array}$ & $\begin{array}{c}0.22 \\
\pm 0.003\end{array}$ & $\begin{array}{c}1.75 \\
\pm 0.07\end{array}$ & $\begin{array}{c}1.75 \\
\pm 0.08\end{array}$ & $\begin{array}{c}226.51 \\
\pm 7.04\end{array}$ & $\begin{array}{c}224.96 \\
\pm 6.49\end{array}$ & $\begin{array}{l}22.07 \\
\pm 1.77\end{array}$ & $\begin{array}{l}22.44 \\
\pm 1.86\end{array}$ & $\begin{array}{l}23.78 \\
\pm 1.48\end{array}$ & $\begin{array}{l}25.09 \\
\pm 1.36\end{array}$ \\
\hline $\begin{array}{c}48 \\
(\mathrm{Wks})\end{array}$ & $\begin{array}{c}0.22 \\
\pm 0.003\end{array}$ & $\begin{array}{c}0.21 \\
\pm 0.005\end{array}$ & $\begin{array}{c}1.76 \\
\pm 0.08\end{array}$ & $\begin{array}{c}1.77 \\
\pm 0.06\end{array}$ & $\begin{array}{c}225.36 \\
\pm 7.61\end{array}$ & $\begin{array}{c}226.14 \\
\pm 6.73\end{array}$ & $\begin{array}{l}22.53 \\
\pm 1.65\end{array}$ & $\begin{array}{l}22.71 \\
\pm 1.80\end{array}$ & $\begin{array}{l}24.01 \\
\pm 1.51\end{array}$ & $\begin{array}{l}24.45 \\
\pm 1.38\end{array}$ \\
\hline $\begin{array}{c}52 \\
\text { (Wks) }\end{array}$ & $\begin{array}{c}0.20 \\
\pm 0.005\end{array}$ & $\begin{array}{c}0.22 \\
\pm 0.003\end{array}$ & $\begin{array}{c}1.76 \\
\pm 0.05\end{array}$ & $\begin{array}{c}1.75 \\
\pm 0.06\end{array}$ & $\begin{array}{c}226.11 \\
\pm 7.29\end{array}$ & $\begin{array}{c}226.89 \\
\pm 7.03\end{array}$ & $\begin{array}{l}22.04 \\
\pm 1.61\end{array}$ & $\begin{array}{l}21.85 \\
\pm 1.73\end{array}$ & $\begin{array}{l}23.94 \\
\pm 1.36\end{array}$ & $\begin{array}{l}24.70 \\
\pm 1.42\end{array}$ \\
\hline
\end{tabular}

$\mathrm{F} .=$ Floor pens system, Con. = Conventional cage system

$A, b, \ldots . .$. Means within each parameter in the same row with different superscript letters are significantly different $(p \leq 0.05)$. 


\section{REFERENCES}

1. Anderson, K.E.; Adams, A.W. and Craig, J.V. 1989. Behaviour adaptation of floorreared White Leghorn pullets to different cage densities and cage shapes during the initial settlingin period. Poultry Science, 68: 70-78.

2. Appleby, M.C. 1984. Factors affecting floor laying by domestic hens: A review. World's poultry Science Journal, 40: 241-249.

3. Broom, D.M. and Knowles, T.G. 1989. The assessment of welfare during the transport and handling of spent hens. $3^{\text {rd }}$ European Symposium on Poultry Welfare. Tours, France. p. 76.

4. Canadian Coalition for Farm Animals. 2005. Canadian wants more human eggs and pork in grocery stores and fast food restaurants. http://www.humanefood.ca/eggindustry.html Accessed June 2007.

5. Cook, N.J.; Renema, R.; Wilkinson, C. and Schaefer, A.L. 2009. Comparisons among serum, egg albumin and yolk concentrations of corticosterone as biomarkers of basal and stimulated adrenocortical activity of laying hens. British Poultry Science, 50: (5) 620-633.

6. Craig, J.V. and Swanson, J.C. 1994. Review. Welfare perspectives on hens kept for egg production. Poultry Science, 73:921-938.

7. Downing, J.A. and Bryden, W. L. 2002. A non-invasive test of stress in laying hens. Rural Industries Research and Development Corporation (RIRDC) Publication No. 01/143. Rural Industries Research and Development Corporation, Kingston, Australia.

8. Downing, J.A. and Bryden, W. L. 2009. The effects of housing laying hens as groups in conventional cages on plasma and egg albumen corticosterone concentrations. Aust. Poult. Sci. Symp. 20: 157-160.

9. Duncan, D.B. 1955. Multiple range and F. test. Biometric, (11): 1-42.

10. Duncan, I.J.H. 2001. The pros and cons of cages. World's Poultry Science Journal, 57: 381-390.

11. Farm Animal Welfare Council. 1986. Egg Production Systems-An Assessment. The Farm Animal Welfare Council, Government Buildings, Hook Rise South, Tolworth, Surbiton, Surrey, UK.

12. Gross, W.B. and Siegel, H.S. 1983. Evaluation of the heterophil/ lymphocyte ratio as a measure of stress in chickens. Avian Disease. 27:972- 979.

13. Hill, J.A. 1983. Indicators of stress in poultry. World's poultry Science Journal, 39: 24- 32. 
14. Johnson, A. L. 1986. Reproduction in the females. Avian Physiology. $4^{\text {th }}$ ed. P. D. Sturkie, ed. Springer-Verlag, New York, NY. $403-431$.

15. Maxwell, M.H.; Hocking, P.M. and Robertson, G.W. 1992. Differential leucocyte responses to various degrees of food restriction in broilers, turkeys and ducks. British poultry Science, 33:177-187.

16. Mc Farlane, J.M. and Curtis, S.E. 1989. Multiple concurrent stressors in chicks. 3. Effects on plasma corticosterone and the heterophil:lymphocyte ratio. Poultry Science, 68:522-527.

17. SAS Institute, Inc. 2000. SAS-User's Guide: Statistics. SAS Inst. Inc., Cary. NC.

18. Siegel, P.B. and Gross, W.B. 2000. Livestock handling and transport. In: Grandin, T. (Ed.), General Principles of Stress and Wellbeing, 2nd ed. CAB International, Wallingham, pp. 27- 41.

19. Simon, J. 1984. Effects of daily corticosterone injection upon plasma glucose, insulin, uric acid and electrolytes and food intake pattern in the chicken. Diabetes Metab. 10: $211-217$.

20. Singh, R.; Cheng, K.M. and Silversides, F.G. 2009a. Production performance and egg quality of four strain of laying hens kept in conventional cages and floor pens. Poultry Science, 88: 256-264.

21. Singh, R.; Cook, N.; Cheng, K.M. and Silversides, F.G. 2009b. Invasive and noninvasive measurement of stress in laying hens kept in conventional cages and in floor pens. Poultry Science 88:1346-1351.

22. Süto , Z.; Horn, P. and Ujvári, J. 1997. The effect of different housing systems on production and egg quality traits of brown and Leghorn type layers. Acta Agraria Kaposváriensis 1: 29 - 35.

23. Tactacan, G.B.; Guenter, W.; Lewis, N.J.; Rodriguez-Lecompte, J. C. and House, J.D. 2009. Performance and welfare of laying hens in conventional and enriched cages Poultry science, 88: 698-707.

24. USDA. 2005. Chickens and eggs. http://usda.mannlib.cornell.edu/reports/nassr/ poultry/pec-bb/2005/ckeg0105.pdf. Accessed June 2007. 


\title{
مقارنة الاداء و الاجهاد الفسيولوجى للاجاج البياض
}

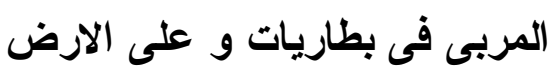

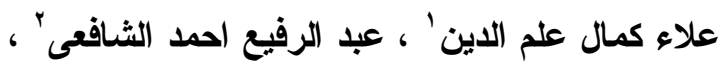

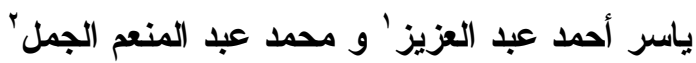 \\ ا . معهد بحوث الانتاج الحيوانى - مركز البحوث الزراعيه - وزارة الزراعه - الدقى - جيزه - مصر. \\ r r r r rلية الزراعه - جامعة الازهر - مدينة نصر - القاهره - مصر.
}

استخدم فى هذه الدر اسة عدد 180 دجاجه LSL أبيض مرباه نربيه أرضيه من عمر يوم.

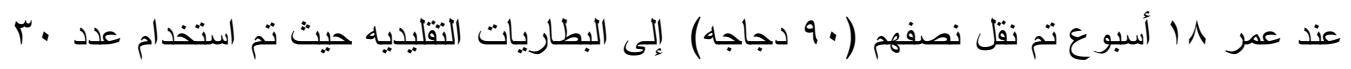

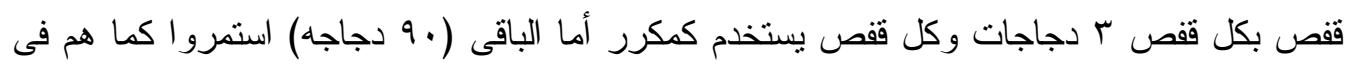

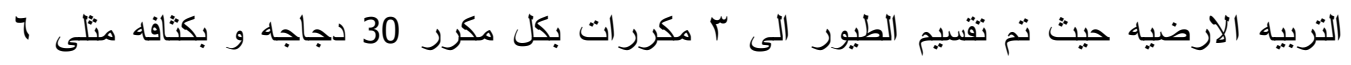

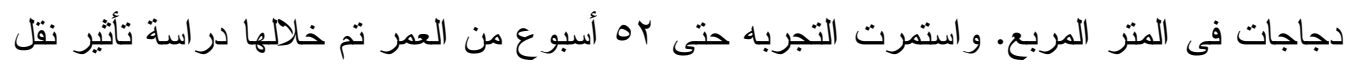

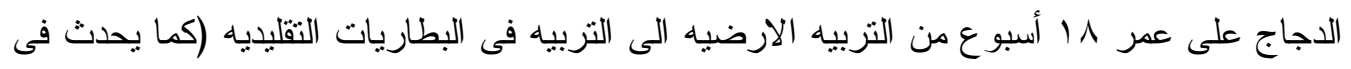
النظام التجارى) على بعض الصفات الانتاجيه و الفسيولوجيه مقارنة بالاجاج الذى أستمرت تربيته فى النظام الارضى لمدة موسم انتاجى.

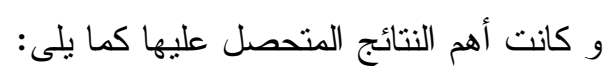

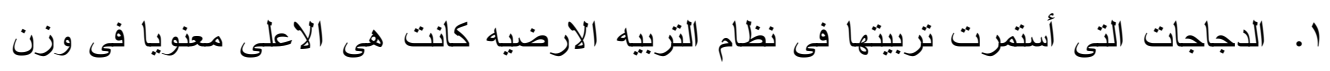

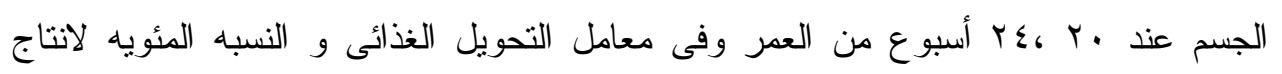

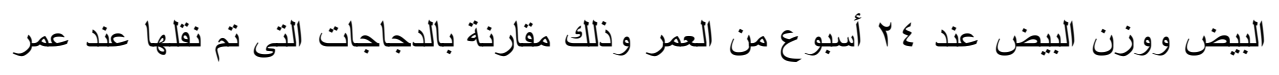

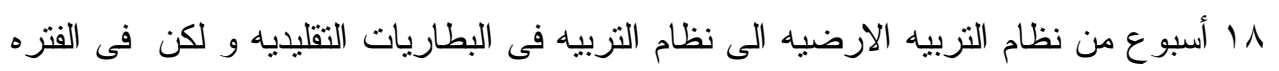

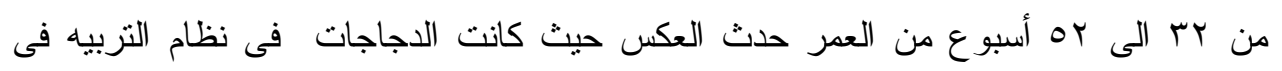
البطاريات التقليديه الاعلى (غير معنوى) فى صن صنات وزن الجسم و النسبه المئويه لانتاج

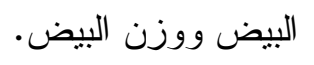

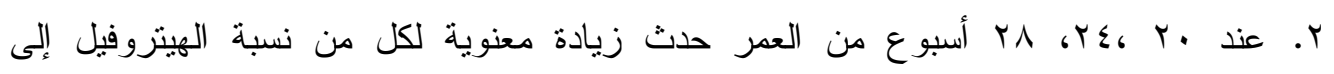

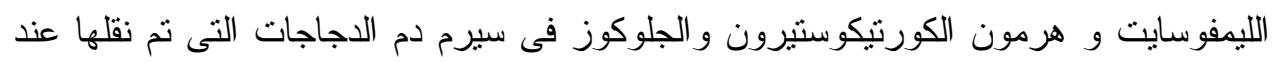

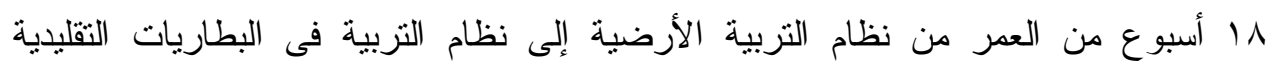

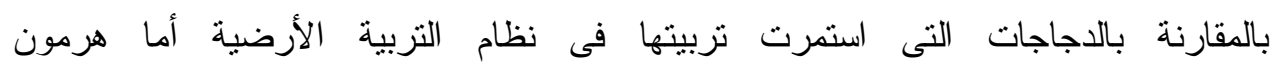

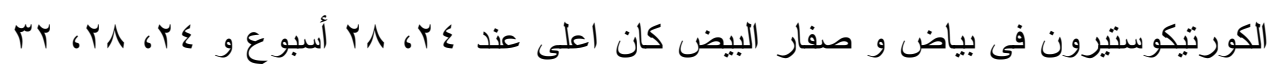

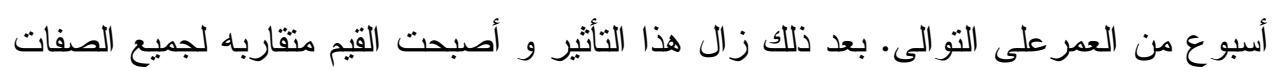

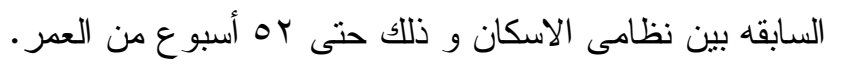




$$
\begin{aligned}
& \text { من النتائج السابقه يمكن أن نستتتج أن } \\
& \text { الاجاجات التى تم نقلها عند عمر 1/ أسبوع من نظام التزبيه الارضيه الى نظام التربيه فى }
\end{aligned}
$$

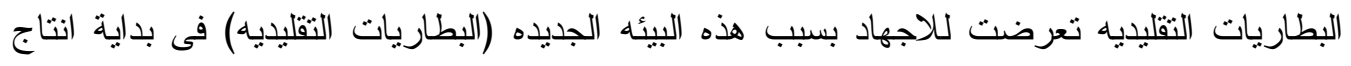

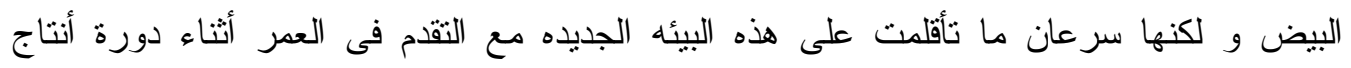

$$
\begin{aligned}
& \text { البيض. لذلك ننصح بنقل الدجاج من نظام التربيه الارضيه الى نظام التربيه فى البطاريات التهات التقليديه }
\end{aligned}
$$

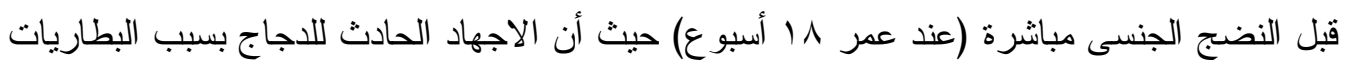

$$
\begin{aligned}
& \text { التقليديه سرعان ما يزول و يحدث اقلمه فسيولوجيه للاجاج تـؤدى الى تحسن فى الصفات الانتاجيه }
\end{aligned}
$$

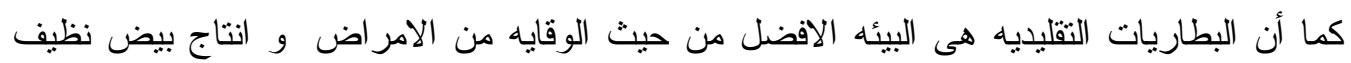

$$
\begin{aligned}
& \text { بالمقارنه بنظام التربيه الارضيه. }
\end{aligned}
$$

